\title{
PENYULUHAN BUDIDAYA TANAMAN HIDROPONIK DI DESA KALENSARI KECAMATAN WIDASARI KABUPATEN INDRAMAYU
}

\author{
Henly Yulina \\ Fakultas Pertanian, Universitas Wiralodra, Indramayu \\ henlyyulina2089@unwir.ac.id
}

\begin{abstract}
Abstrak
Kebutuhan konsumsi masyarakat bukan hanya kebutuhan pokok seperti beras, jagung, gandum, dan ketela. Tetapi juga kebutuhan sayur-sayuran dan buah-buahan sebagai pelengkap kebutuhan nutrisi tubuh. Pengembangan komoditas sayuran secara kuantitas dan kualitas dihadapkan pada semakin sempitnya lahan pertanian. Hidroponik adalah cara bercocok tanam yang tidak menggunakan media tanah serta dapat memanfaatkan lahan- lahan yang sempit atau kurang produktif, seperti lahan pekarangan rumah. Penyuluhan dan pelatihan telah dilakukan secara terprogram di Desa Kalensari Kecamatan Widasari Kabupaten Indramayu dengan sasaran Ibu-ibu PKK. Penyuluhan ini memberikan pengetahuan baru bagi warga untuk dapat mengoptimalkan pekarangan rumah mereka sehingga dapat bermanfaat baik dalam segi estetika bahkan kedepannya dalam segi perekonomian, namun terdapat kendala dalam penyerapan materi secara keseluruhan karena peserta masih banyak yang belum bisa berbahasa Indonesia dengan baik dan benar.
\end{abstract}

Kata kunci: budidaya, hidroponik, desa kalensari

\begin{abstract}
Community consumption needs are not only basic needs such as rice, corn, wheat, and cassava. But also need vegetables and fruits to complement the body's nutritional needs. The development of vegetable commodities in quantity and quality is faced with the narrowing of agricultural land. Hydroponics is a method of farming that does not use soil media and can use narrow or less productive lands such as home yards.Counseling and training have been programmed in Kalensari Village, Widasari Subdistrict, Indramayu Regency with the target of PKK women's. This counseling provides new knowledge for participants to be able to optimize their home yards so that they can be beneficial both in terms of aesthetics and even in the future in terms of the economy. But there are obstacles in the feedback of material because there are still many participants who cannot speak Indonesian well and correctly.
\end{abstract}

Keywords: cultivation, hydroponics, kalensari village

\section{A. Pendahuluan}

Desa Kalensari masuk dalam wilayah Kecamatan Widasari Kabupaten Indramayu dengan ketinggian wilayah berada pada $15 \mathrm{mdpl}$, dan secara geografis dikelilingi oleh Desa Widasari di sebelah timur, Desa Malangsari di sebelah selatan, Desa Bunder di sebelah Barat dan Desa Ujungaris di sebelah utara.Wilayahnya terbagi kedalam 2 RW dan 4 RT. Dengan luas wilayah berupa pemukiman sebesar 14,25 hektar dan luas wilayah sawah sebesar 274 hektar.

Jumlah penduduk Desa Kalensari sebanyak 1.152 jiwa. Mata pencaharian di Desa Kalensari cukup bervariasi dengan mayoritas di sektor pertanian. Faktor ini 
didukung dengan terdapatnya lahan pertanian yang cukup luas. Dari sektor pertanian, padi menjadi tanaman yang pada umumnya dibudidayakan oleh sebagian besar warga Desa Kalensari. Hal ini dapat dilihat dari hamparan sawah yang cukup luas.

Kebutuhan konsumsi masyarakat bukan hanya kebutuhan pokok seperti beras, jagung, gandum, dan ketela. Tetapi juga kebutuhan sayur-sayuran dan buah-buahan sebagai pelengkap kebutuhan nutrisi tubuh. Berdasarkan data Sasaran Konsumsi Energi, Protein dan Skor Pola Pangan Harapan (PPH) konsumsi energi per kelompok pangan (kkal/kapita/hari) untuk buah dan sayur meningkat dari 111 hingga 115 dari tahun 2015 - 2019 (Pusat Data dan Sistem Informasi Pertanian, 2017). Yang dimaksud dengan Pola Pangan Harapan adalah situasi konsumsi pangan penduduk, baik jumlah maupun komposisi pangan menurut jenis pangan. Skor PPH tercatat sebesar 84,1 pada tahun 2015 menjadi 92,5 pada tahun 2019. Semakin tinggi skor PPH, konsumsi pangan semakin beragam dan bergizi seimbang (maksimal 100). Skor PPH merupakan indikator mutu gizi dan keragaman konsumsi pangan sehingga dapat digunakan untuk merencanakan kebutuhan konsumsi pangan pada tahun-tahun mendatang.

Pada peringatan hari gizi nasional tahun 2017 disampaikan bahwa melalui survei sosial ekonomi nasional BPS tahun 2016 penduduk Indonesia hampir seluruhnya mengkonsumsi sayur yaitu 97,29\% dan jenis sayuran favorit yaitu bayam, kangkung, kacang panjang, tomat dan terong. Kecenderungan peningkatan konsumsi terutama sayuran mencerminkan perbaikan kondisi kesehatan masyarakat Indonesia pada umumnya, apabila secara kuantitas dibarengi dengan kualitas produk yang dihasilkan. Pengembangan komoditas sayuran secara kuantitas dan kualitas dihadapkan pada semakin sempitnya lahan pertanian (Swastika, dkk., 2018).

Berdasarkan perkembangan skor PPH, untuk mencapai keberagaman ketersediaan pangan yang ideal dan memenuhi Angka Kecukupan Gizi (AKG) tingkat ketersediaan yang dianjurkan, ketersediaan kelompok pangan hewani serta sayuran dan buah perlu ditingkatkan. Hal ini yang mendasari Kementerian Pertanian melalui Direktorat Jenderal Hortikultura membuat beberapa program antara lain Peningkatan produksi dan budidaya hortikultura dan bimbingan teknis budidaya untuk kelompok wanita dalam pemanfaatan pekarangan, Sosialisasi/gerakan konsumsi sayur dan buahbuahan, Dukungan benih/bibit sayuran dan buah untuk kelompok wanita dalam pemanfaatan pekarangan.

Hampir seluruh lahan di wilayah Desa Kalensari digunakan untuk menanam padi, sehingga diperlukan cara tanam lain untuk dapat memenuhi kebutuhan sayursayuran dan buah-buahan dengan memanfaatkan lahan-lahan pekarangan di pemukiman warga masing-masing. Lahan pekarangan merupakan salah satu modal jika ingin berusaha tani dalam skala rumah tangga.

Hidroponik adalah cara bercocok tanam yang tidak menggunakan media tanah serta dapat memanfaatkan lahan- lahan yang sempit atau kurang produktif, seperti lahan pekarangan rumah. Jenis tanaman yang dapat ditanam dengan sistem hidroponik antara lain bunga (misal: krisan, gerberra, anggrek, kaktus), sayur - sayuran (misal: selada, sawi, tomat, wortel,asparagus, brokoli, cabe, terong), buah - buahan (misal: melon, tomat,mentimun,semangka, strawberi) dan juga umbi - umbian. Pada prinsipnya tanaman dapat hidup di tanah karena tersedianya nutrisi dan jika nutrisi tersebut dapat 
disediakan dalam air dengan perlakuan maka tanaman juga dapat hidup dan memberikan hasil yang sama (Pascual., et al, 2018).

Prinsip dasar hidroponik dibagi menjadi dua yaitu hidroponik substrat dan NFT (Nutrient Film Technique). Kedua bentuk hidroponik tersebut, dapat dibuat tenikteknik baru yang dapat disesuaikan dengan kondisi keuangan dan ruang yang tersedia.(1) Hidroponik Substrat. Hidroponik substrat tidak menggunakan air sebagai media, tetapi menggunakan media padat (bukan tanah) yang dapat menyerap atau menyediakan nutrisi, air, dan oksigen serta mendukung akar tanaman seperti halnya fungsi tanah. Media substrat hidroponik tidak boleh mengandung racun (toksik). Beberapa contoh media yang mengandung racun adalah sebagai berikut: (1) Serbuk gergaji, kadang-kadang mengandung garam dapur $(\mathrm{NaCl})$ yang tinggi akibat dari kayu yang pernah diletakkan di laut, sehingga serbuk gergaji harus dicuci di air tawar sebelum digunakan sebagai media tanam. (2) Media batu apung dan pasir yang berasal dari laut, karena mengandung $\mathrm{CaCO} 3$ sangat tinggi. (2). Hydroponic NFT (Nutrient Film Technique) NTF merupakan model budidaya dengan meletakkan akar tanaman pada lapisan air yang dangkal. Air tersebut tersikulasi dan mengandung nutrisi sesuai kebutuhan tanaman. Perakaran dapat berkembang didalam larutan nutrisi, karena disekitar perakaran terdapat selapis larutan nutrisi maka sistem dikenal dengan nama NFT. Kelebihan air akan mengurangi jumlah oksigen, oleh sebab itu lapisan nutrisi dalam system NFT dibuat maksimal tinggi larutan $3 \mathrm{~mm}$, sehingga kebutuhan air (nutrisi) dan oksigen dapat terpenuhi (Roidah, 2014).

Faktor nutrisi menjadi salah satu faktor penentu yang paling penting dari hasil dan kualitas tanaman. Larutan nutrisi yang paling mendasar adalah Nitrogen $(\mathrm{N})$, Fosfor (P), Kalium (K), Kalsium (Ca), Magnesium (Mg) dan Sulfur (S) yang juga dilengkapi dengan mikronutrien. Tanaman menyerap ion dari larutan nutrisi yang diberikan secara terus menerus dalam tingkatan konsentrasi yang rendah. Dari beberapa hasil penelitian sebelumnya bahwa nutrisi dalam proporsi yang tinggi tidak dimanfaatkan oleh tanaman dan juga tidak mempengaruhi produksi tanaman. Larutan nutrisi dengan konsentrasi tinggi menyebabkan penyerapan nutrisi yang berlebihan dan dapat menyebabkan kecacunan pada tanaman, walaupun beberapa penelitian menyebutkan ada juga pengaruh positif seperti pembungaan yang lebih cepat pada Salvia sp. atau meningkatnya berat kering buah, berat total buah dan jumlah lycopene pada tomat (Libia., et al, 2012).

Media tumbuh yang ideal untuk hidroponik antara lain dapat menopang pertumbuhan tanaman, memiliki pori untuk aerasi, tidak menyumbat instalasi hidroponik, dan tidak mempengaruhi larutan nutrisi. Media tidak berfungsi menyediakan nutrisi dan harus bersifat lembam (Orsini, F. et al, 2012). Media tanam selain tanah yang dapat digunakan antara lain air, busa, kerikil, rockwool, pasir, serbuk gergaji, gambut, sabut kelapa, perlit, batu apung, kulit kacang, poliester, atau vermikulit (Resh, H.M., 2013). Karakteristik media yang baik dalam Munoz (2010) antara lain ukuran partikel antara $2-7 \mathrm{~mm}$, mampu mempertahankan kelembaban dan mengeluarkan kelebihan air, tidak mudah terdegradasi dan terurai, bebas dari mikroorganisme yang berbahaya bagi kesehatan manusia atau tanaman, tidak terkontaminasi dengan limbah industri, mudah diperoleh dan dipindahkan. 
Cara bercocok tanam secara hidroponik sebenarnya sudah banyak dipakai oleh beberapa masyarakat untuk memanfaatkan lahan yang tidak terlalu luas. Banyak keuntungan dan manfaat yang dapat diperoleh dari sistem tersebut. Sistem ini dapat menguntungkan dari kualitas dan kuantitas hasil pertaniannya, serta dapat memaksimalkan lahan pertanian yang ada karena tidak membutuhkan lahan yang banyak (Roidah, 2014).

Keuntungan Sistem Hidroponik adalah (1) Keberhasilan tanaman untuk tumbuh dan berproduksi lebih terjamin. (2) Perawatan lebih praktis dan gangguan hama lebih terkontrol.(3) Pemakaian pupuk lebih hemat (efisien).(4)Tanaman yang mati lebih mudah diganti dengan tanaman yang baru . (5) Tidak membutuhkan banyak tenaga kasar karena metode kerja lebih hemat dan memiliki standarisasi.(6) Tanaman dapat tumbuh lebih pesat dan dengan keadaan yang tidak kotor dan rusak.(7) Hasil produksi lebih continue dan lebih tinggi dibanding dengan penanama ditanah. (8) Harga jual hidroponik lebih tinggi dari produk non-hydroponic.(9) Beberapa jenis tanaman dapat dibudidayakan di luar musim.(10) Tidak ada resiko kebanjiran,erosi, kekeringan, atau ketergantungan dengan dapat dilakukan pada lahan atau ruang yang terbatas, misalnya di atap, dapur atau garasi. Kelemahan Sistem Hidroponik adalah (1) Investasi awal yang mahal. (2) Memerlukan keterampilan khusus untuk menimbang dan meramu bahan kimia. (3) Ketersediaan dan pemeliharaan perangkat hidroponik agak sulit.

\section{B. $\quad$ Metode}

\section{Kerangka Pemecahan Masalah}

Dalam upaya untuk memberikan pemahaman baru dan pengetahuan kepada masyarakat tentang hidroponik dilakukan melalui penyuluhan, yaitu dengan pemberian dan pemaparan materi tentang budidaya tanaman hidroponik dalam bentuk presentasi dan tanya jawab serta pelatihan yaitu praktek secara langsung cara pembuatan larutan nutrisi untuk tanaman hidroponik.

\section{Realisasi Pemecahan Masalah}

Penyuluhan dan pelatihan pembuatan larutan nutrisi di Desa Kalensari, Kecamatan Widasari, Kabupaten Indramayu dilaksanakan di pelataran Kantor Desa Kalensari selama 1 hari yang diikuti oleh ibu-ibu program Pembinaan Kesejahteraan Keluarga (PKK) Desa Kalensari dan didampingi oleh mahasiswa/i Kuliah Kerja Nyata (KKN) Universitas Wiralodra, Indramayu. Pemberian dan pemaparan materi dilakukan dengan metode tanya jawab, kemudian dilanjutkan dengan praktek pembuatan larutan nutrisi.

\section{Metode Pelaksanaan}

1. Melakukan sosilisasi tentang program pengabdian kepada masyarakat yang akan dilaksanakan di Desa Kalensari. Sosialisasi dilakukan dengan bertanya langsung kepada kepala desa mengenai program tahunan yang akan dilakukan di Desa Kalensari disesuaikan dengan Program Kerja (Proker) mahasiswa/i KKN Universitas Wiralodra.

2. Berkoordinasi dengan perangkat desa serta kader Ibu-ibu PKK untuk teknik, waktu, dan tempat pelaksanaan. 
3. Melakukan penyuluhan tentang budidaya tanaman hidroponik

4. Melaksanakan praktek pembuatan larutan nutrisi.

5. Melakukan evaluasi kegiatan dengan mahasiswa/i KKN.

Evaluasi dilakukan setelah penyuluhan dan pelatihan selesai dilaksanakan di posko tempat mahasiswa/i KKN menginap dan melaksanakan setiap program kerja selama masa KKN.

\section{Hasil dan Pembahasan}

Program pengabdian kepada masyarakat berupa penyuluhan dan pelatihan yang diikuti oleh Ibu-ibu PKK Desa Kalensari, Kecamatan Widasari, Kabupaten Indramayu. diikuti secara antusias dengan banyaknya pertanyaan yang diberikan selama kegiatan. Ibu-ibu PKK mendapatkan pengetahuan baru tentang cara menanam, media apa saja yang diperlukan untuk menanam tanaman hidroponik, dan jenis tanaman apa saja yang dapat ditanam, sehingga lahan pekarangan di depan rumah mereka bisa dimanfaatkan.

Materi penyuluhan yang disampaikan berupa power point dibawah ini:

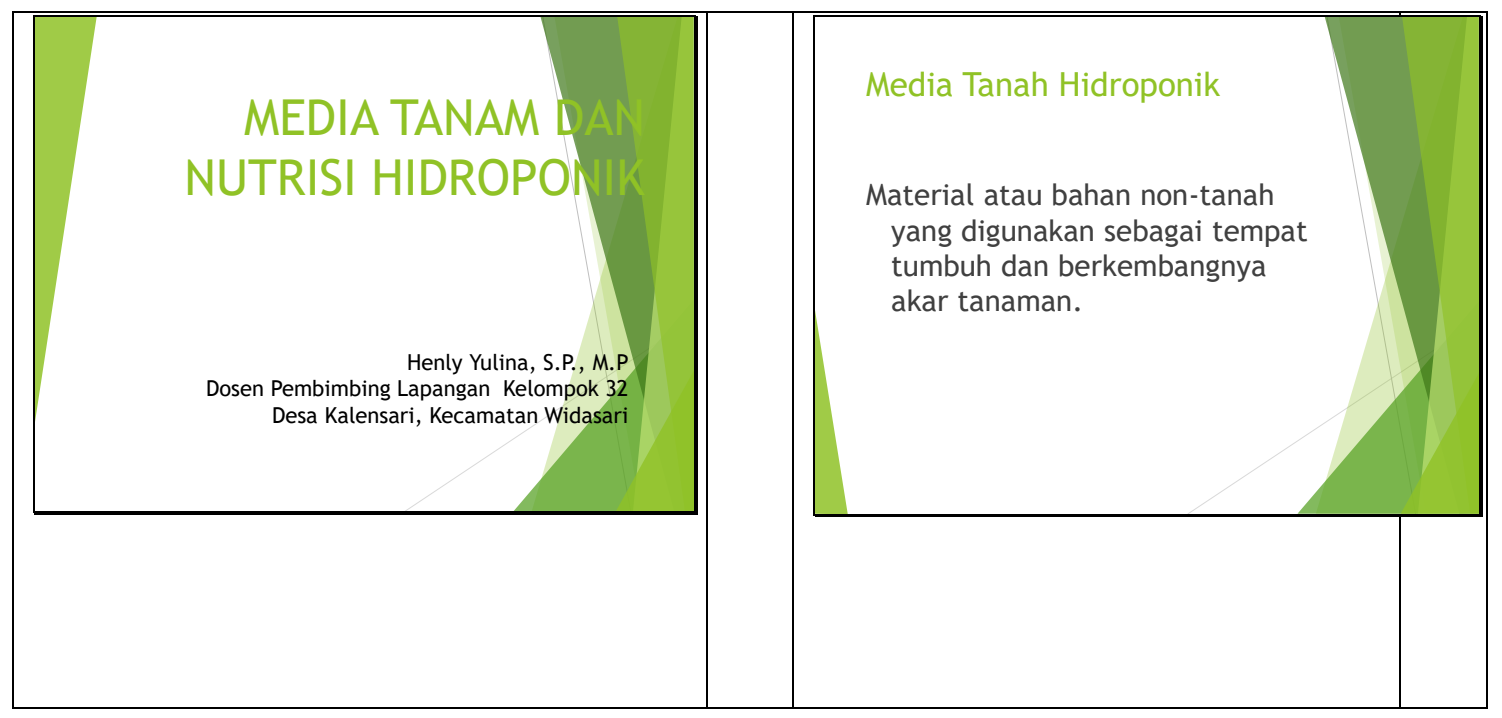




\section{ABDI WIRALODRA \\ JURNAL PENGABDIAN KEPADA MASYARAKAT \\ E-ISSN}

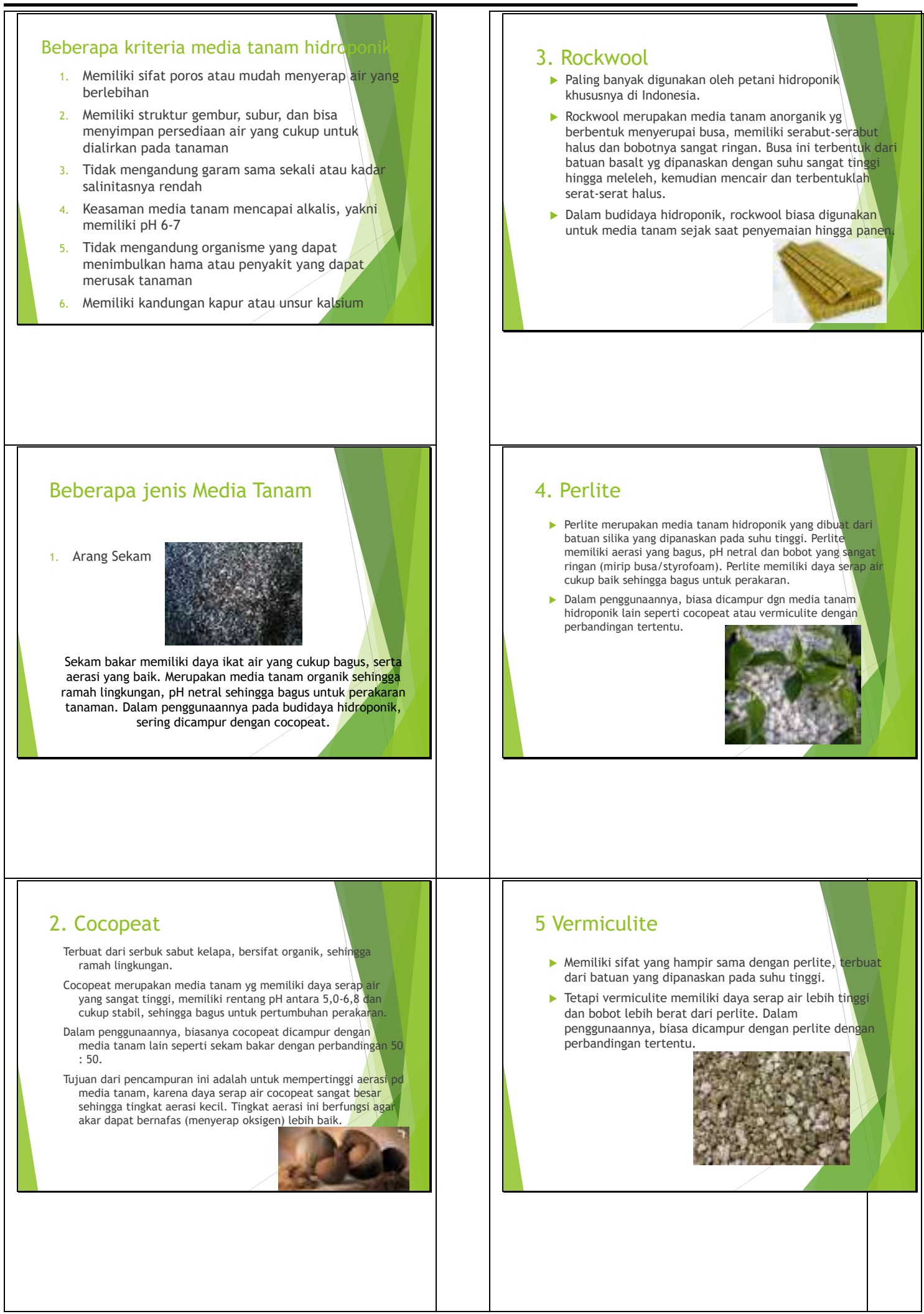




\section{ABDI WIRALODRA \\ ISSN 2656-5501 (Print) \\ JURNAL PENGABDIAN KEPADA MASYARAKAT \\ E-ISSN}

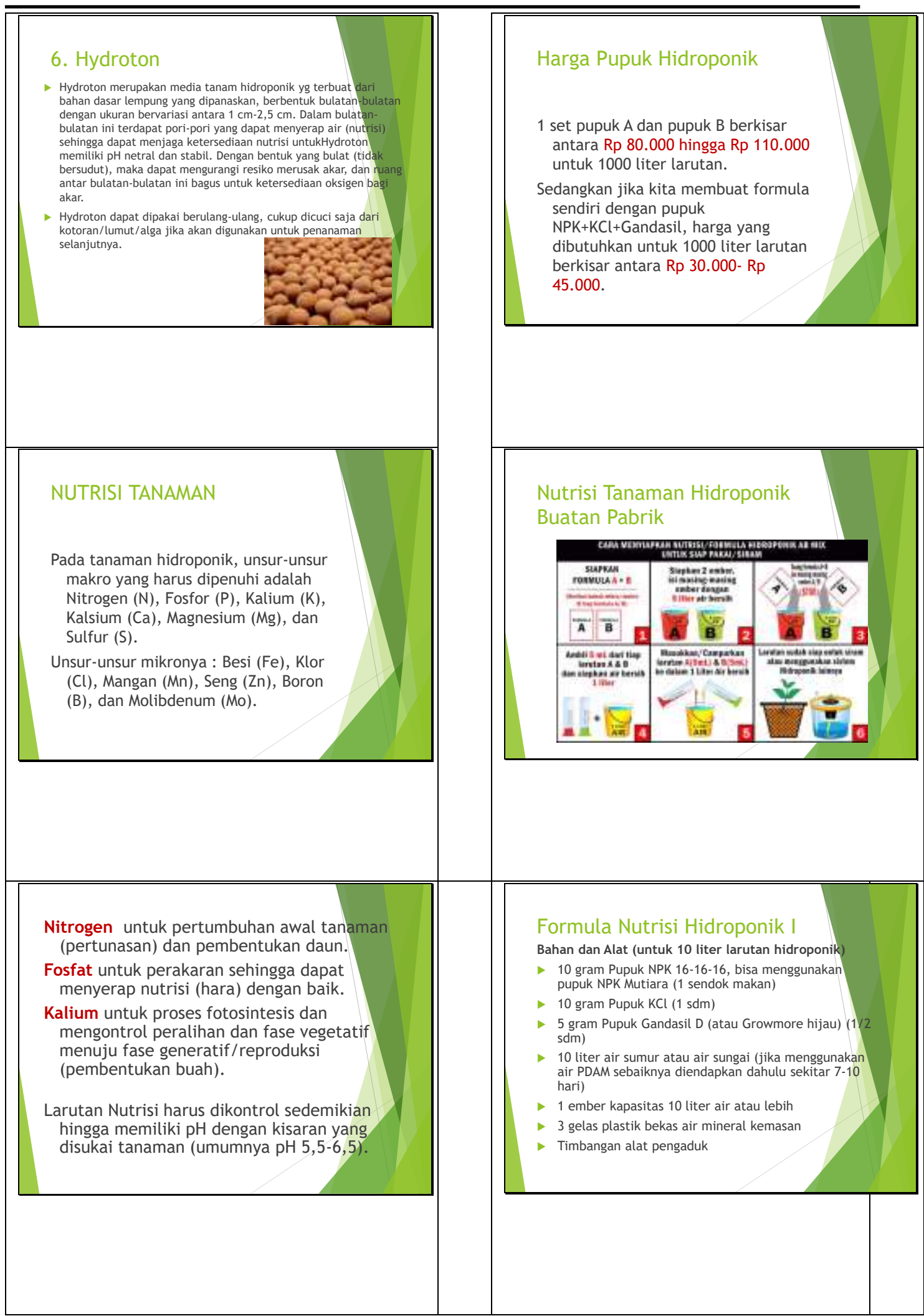




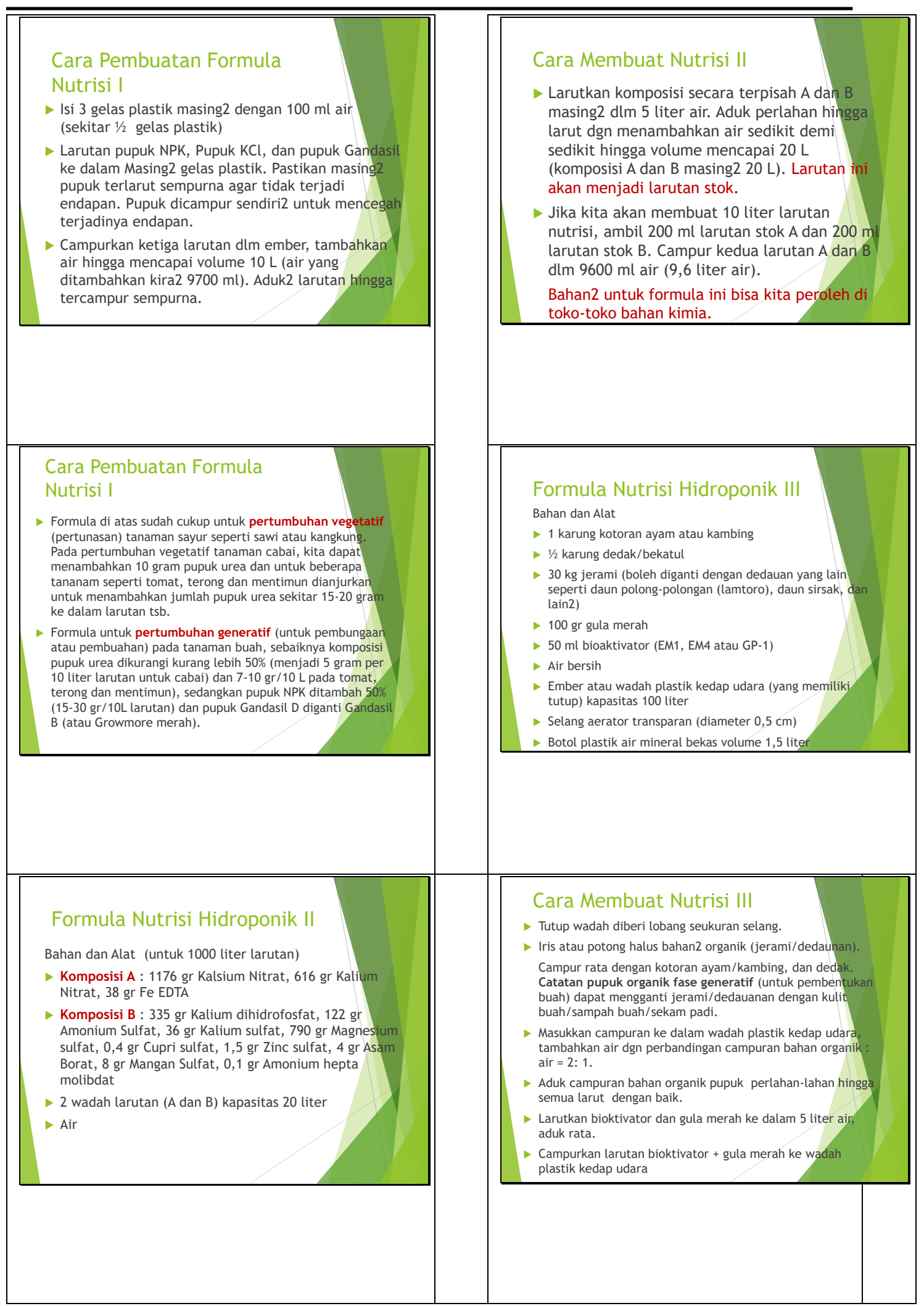




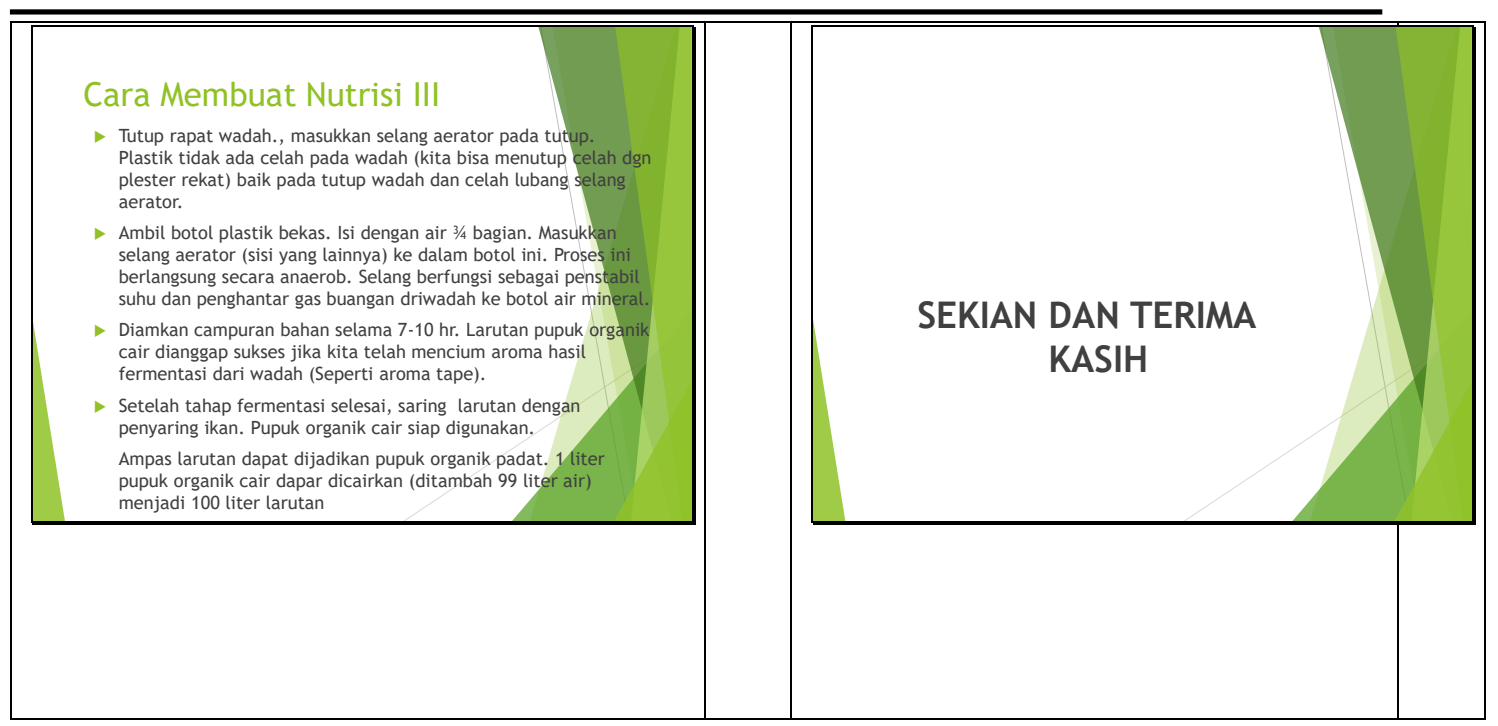

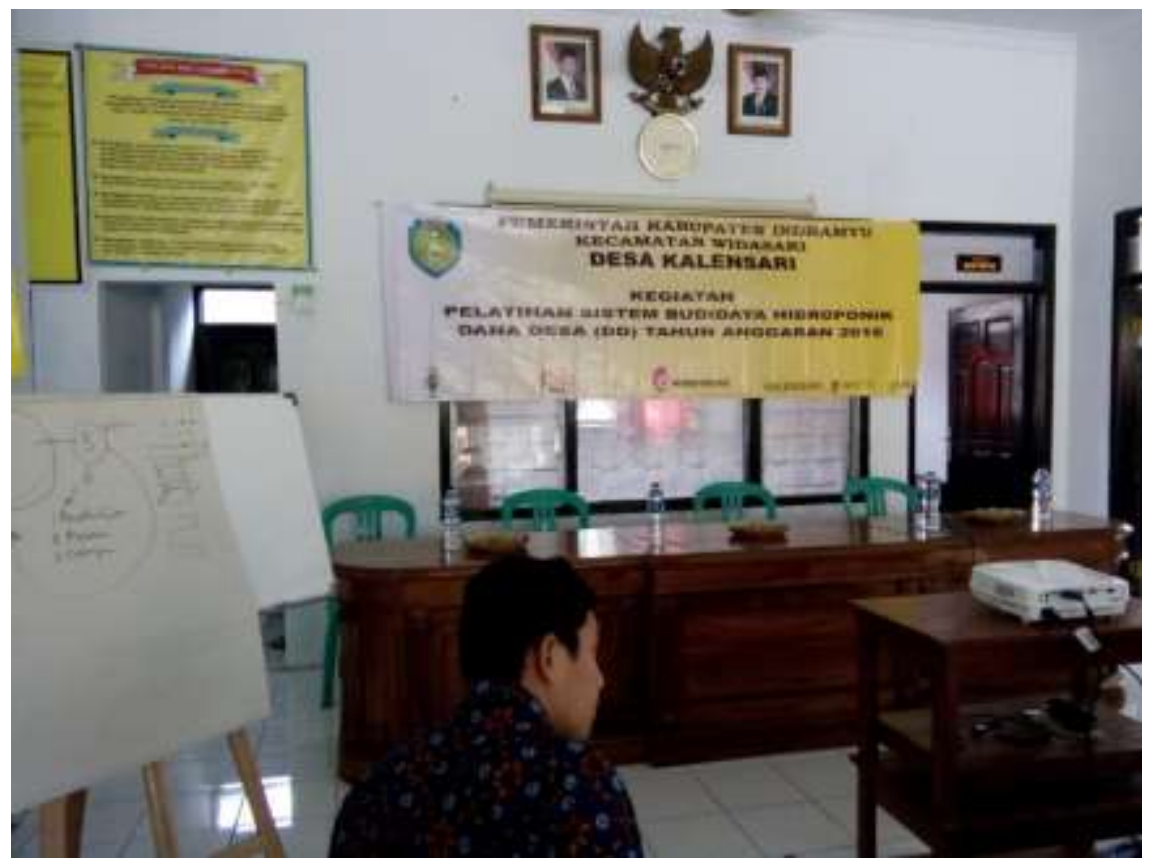

Gambar 1. Persiapan sebelum Penyuluhan dan Pelatihan di mulai 


$\begin{array}{ll}\text { ABDI WIRALODRA } & \text { ISSN 2656-5501 (Print) } \\ \text { JURNAL PENGABDIAN KEPADA MASYARAKAT } & \text { E-ISSN }\end{array}$

JURNAL PENGABDIAN KEPADA MASYARAKAT
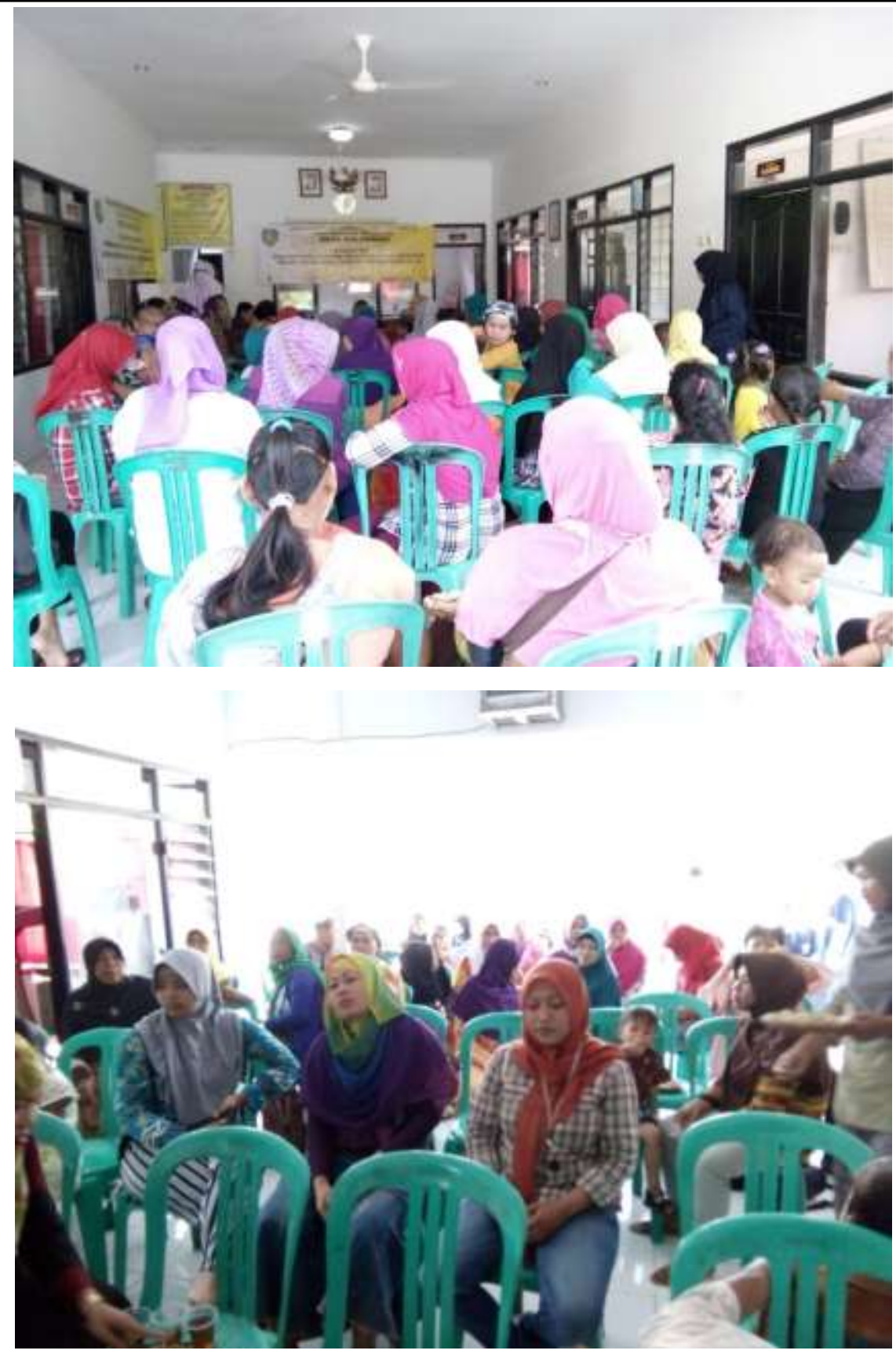

Gambar 2. Ibu-ibu PKK sebagai Peserta Penyuluhan dan Pelatihan 


$\begin{array}{ll}\begin{array}{l}\text { ABDI WIRALODRA } \\ \text { JURNAL PENGABDIAN KEPADA MASYARAKAT }\end{array} & \text { ISSN 2656-5501 (Print) } \\ \text { E-ISSN }\end{array}$

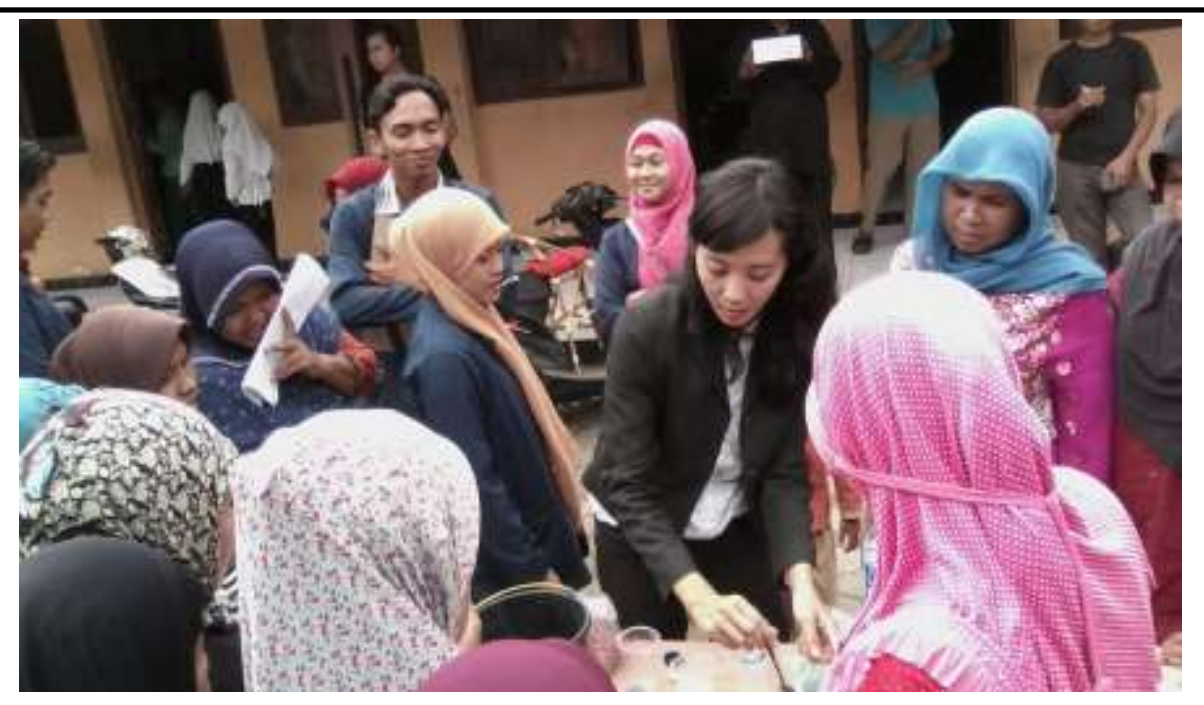

Gambar 3. Pelatihan Pembuatan Larutan Nutrisi

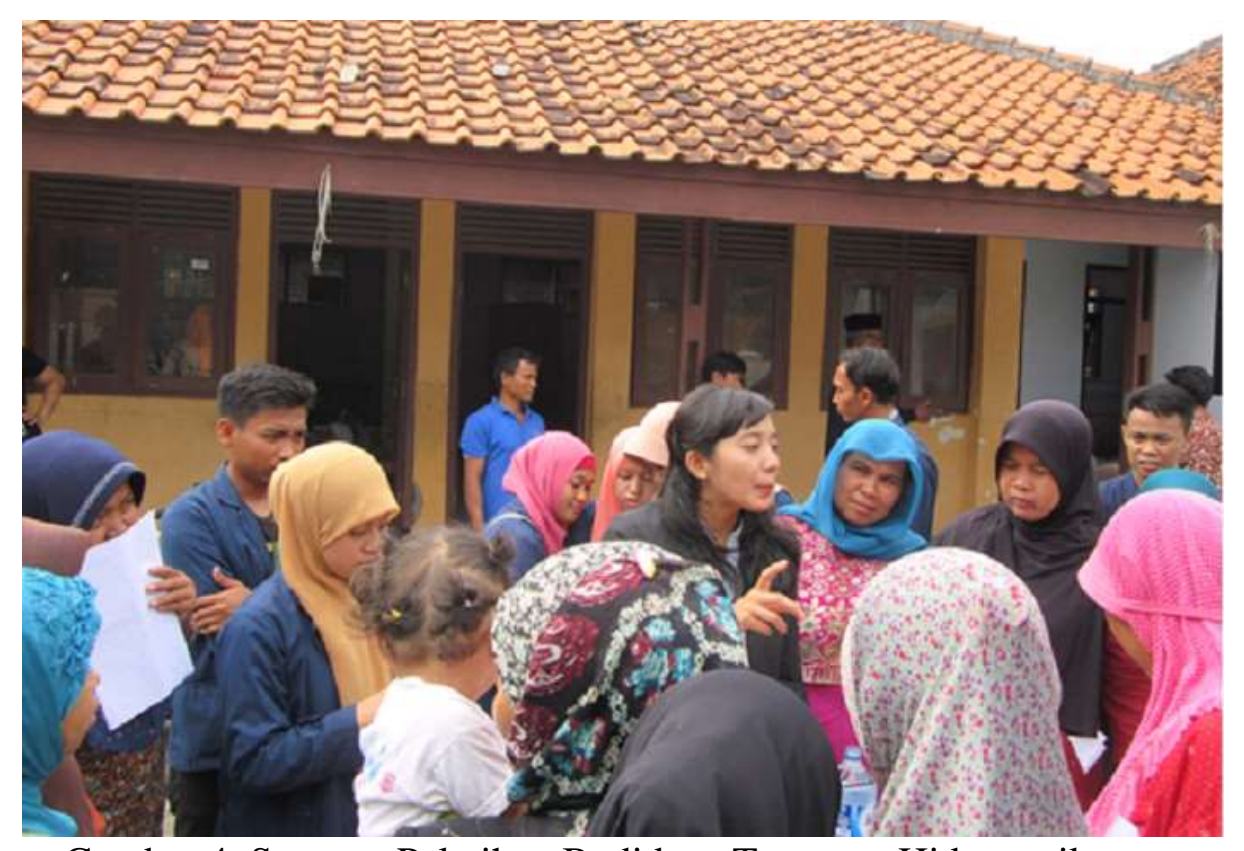

Gambar 4. Suasana Pelatihan Budidaya Tanaman Hidroponik yang diikuti Ibu-ibu PKK di Desa Kalensari di dampingi mahasiswa/i KKN

Kendala yang dialami saat penyuluhan dan pelatihan adalah para peserta yang kebanyakan belum bisa berbahasa Indonesia dengan baik dan benar, sehingga materi yang disampaikan belum terserap secara optimal. Dari hasil survey yang dilakukan, peserta pelatihan mengatakan bahwa penyuluhan dan pelatihan cara budidaya tanaman hidroponik sangat bermanfaat bagi beliau dan ibu-ibu PKK lain yang mengikuti 
kegiatan karena dapat menambah pengetahuan dan pemahaman mereka yang asalnya tidak tahu cara mengoptimalkan lahan pekarangan mereka sekarang bisa dioptimalkan dengan cara hidroponik. Namun saja masih terkendala dengan cara pencampuran dosis pupuk dalam pembuatan larutan nutrisinya. Selain ini suasana yang panas dan ricuh karena banyaknya jumlah peserta yang hadir membuat penjelasan sulit didengar, sehingga hanya sebagian yang dapat dipahami oleh peserta.

\section{Kesimpulan dan Saran}

Kesimpulan dari penyuluhan dan pelatihan adalah

1. Peserta di Desa Kalensari merasa antusias dengan kegiatan penyuluhan dan pelatihan budidaya tanaman hidroponik yang telah dilaksanakan.

2. Penyuluhan dan pelatihan memberikan pengetahuan dan pemahaman baru bagi warga untuk dapat mengoptimalkan pekarangan rumah mereka sehingga dapat bermanfaat baik dalam segi estetika bahkan kedepannya dalam segi perekonomian.

3. Terdapat kendala dalam penyerapan materi secara keseluruhan karena peserta masih banyak yang belum bisa berbahasa Indonesia dengan baik dan benar.

Saran

1. Penyuluhan dan pelatihan dapat ditindaklanjuti per-RT dengan didampingi oleh pendamping dari masyarakat sekitar yang berkompeten di bidang pertanian, sehingga materi bisa terserap secara optimal dan bahasa yang digunakan dapat menggunakan bahasa daerah setempat.

2. Adanya aplikasi langsung menanam tanaman hidroponik pada pekarangan rumah setiap warga Desa Kalensari.

\section{Daftar Pustaka}

Libia I. Trejo-Téllez and Fernando C. Gómez-Merino (2012). Nutrient Solutions for Hydroponic Systems, Hydroponics - A Standard Methodology for Plant Biological Researches, Dr. Toshiki Asao (Ed.), ISBN: 978- 953-51-0386-8.

Munoz, 2010, Hydropnics Home-based Vegetable Production System Manual, InterAmerican Institute for Cooperation on Agriculture, Guyana.

Narasita, D. 2016. Pemerintah Desa Kalensari. http://www.kalensari-widasari.desa.id. (diakses 1 Juli 2019).

Orsini, F et al, 2012, Technical manual, URBAN VEGETABLE PRODUCTION, Hortis - Horticulture in towns for inclusion and socialization (526476-LLP-12012-1, IT GRUNDTVIG-GMP).

Pascual M. P, Gina A. Lorenzo, Arneil G. Gabriel, 2018, Vertical Farming Using Hydroponic System: Towrd a Sustainable Onion Production in Nueva Ecija, Philippines

Pusat Data dan Sistem Informasi Pertanian (2017). BULETIN KONSUMSI PANGAN. Vol 8 No. 1, Pusat Data Dan Sistem Informasi Pertanian, Kementerian Pertanian.

Resh H.M, 2013, Hydroponic Food Production, A Definitive Guidebook for the Advanced Home Gardener and the Commercial Hydroponic Grower, CRC Press. 


\section{ABDI WIRALODRA \\ ISSN 2656-5501 (Print) \\ JURNAL PENGABDIAN KEPADA MASYARAKAT \\ E-ISSN}

Roidah, I. Syamsu. (2014). Pemanfaatan Lahan dengan Menggunakan Sistem Hidroponik. Jurnal Universitas Tulungagung BONOROWO, vol 1, no 2, 43-50.

Swastika, S., A. Yulfida, dan Y. Sumitro. (2018). Budidaya Sayuran Hidroponik Bertanam Tanpa Media Tanah. Kementerian Pertanian. Badan Penelitian dan Pengembangan Pertanian. Balai Pengkajian Teknologi Pertanian (BPTP) Riau. ISBN 978-602-8952-21-7. 